\title{
Causes of Acute Exacerbation of Chronic Hepatitis B Infection: A Report of Case Series
}

\author{
Kronik Hepatit B Olgularında Akut Alevlenme Nedenleri: Bir Olgu Serisi
}

\author{
Çiğdem MOROĞLU1, Necla TÜLEK1, Ebru AKTEPE1, Meliha Çağla SÖNMEZER1, Metin ÖZSOY1, \\ Günay ERTEM TUNCER1, Fatma Şebnem ERDINÇ1, Murat KEKILLI2
}

${ }^{1}$ Ankara Training and Research Hospital, Clinic of Infectious Diseases and Clinical Microbiology, Ankara, Turkey

${ }^{2}$ Ankara Training and Research Hospital, Clinic of Gastroenterology, Ankara, Turkey

\begin{abstract}
Objective: In the course of chronic hepatitis B infection, acute exacerbations characterized by high ALT and HBV DNA levels may occur. Sometimes icterus and hepatic decompensation may develop in severe cases. In this study, we evaluated characteristics of patients who were diagnosed as having acute exacerbation of chronic hepatitis B and the reasons that lead to exacerbation. Materials and Methods: Patients with acute exacerbation of chronic hepatitis B followed up in a training and research hospital clinic between 2010 and 2014, were retrospectively evaluated. Acute exacerbation was diagnosed by detection of 5 -fold increase or more than twice of the previous values in ALT levels and elevation of HBV DNA (>105 I.U) in patients with chronic hepatitis. Age, gender, known duration of hepatitis $B$ infection, medication, HBeAg positivity and anti-HBc IgM, ALT, AST, albumin, prothrombin time and HBV DNA levels of patients were recorded. The causes of acute exacerbation were revised.

Results: Fourteen patients (eight females; $57.1 \%$, six males; $42.9 \%$ ) were included in the study. The average age was 41.5 years (range: 20-71 years). All patients had hepatitis B infection diagnosis for at least one year. Pregnancy and discontinuation of therapy were the causes of acute exacerbation in nearly half of the patients. Other reasons were detected as spontaneous reactivation, $\mathrm{HBeAg}$ seroconversion during interferon treatment, herbal use, alcohol use, immunosuppressive therapy and an infectious disease.

Conclusion: Pregnancy and treatment non-adherence were found to be the most frequent causes of exacerbations. Education and close monitoring of patients are important in preventig acute exacerbations.
\end{abstract}

Key Words: Chronic hepatitis B, acute exacerbation, reactivation, acute failure-on-chronic liver
ÖZET

Amaç: Kronik hepatit B seyri esnasında HBV DNA ve ALT yükselmesi ile karekterize akut alevlenmeler olabilir. Bazı olgularda sarılık ve hepatik dekompensasyon gelişebilir. Bu çalışmada kronik hepatit B akut alevlenme olgularının özellikleri ve alevlenmeye yol açan nedenler irdelenmiştir.

Gereç ve Yöntemler: Bir eğitim ve araştırma hastanesi kliniğinde 20102014 yılları arasında kronik hepatit B akut alevlenme tanısı konulan olgular retrospektif olarak incelendi. Akut alevlenme tanısı, kronik hepatitli hastalarda ALT düzeylerinde 5 kat artış veya daha önceki değerinin 2 katından fazla artış ve HBV DNA düzeylerinin yüksekliği (>105 I.U) ile konuldu. Hastaların yaş, cinsiyet, bilinen hepatit süresi, kullandığı ilaçlar, HBeAg pozitifliği, anti-HBclgM, serum ALT, AST düzeyleri, total protein, albümin, protrombin zamanı, HBV DNA düzeyleri kaydedildi. Alevlenmeye yol açan nedenler gözden geçirildi. Bulgular: Çalışmaya 14 hasta (8 kadın; \%57,1, 6 erkek; \%42,9) dahil edilmiştir. Yaş ortalaması 41,5 yıldır (dağıım; 20-71 yaş). Tüm hastalarda en az bir yıldır kronik hepatit tanısı bulunmaktaydı. Hastaların yaklaşık yarısında akut alevlenme nedeni gebelik ve tedavinin bırakılması idi. Diğer nedenler spontan reaktivasyon, interferon tedavisi sırasında serokonversiyon, bitkisel ilaç kullanımı, alkol kullanımı, immünsupresif tedavi ve infeksiyon olarak tespit edildi.

Sonuç: Gebelik ve tedavi uyumsuzluğu akut alevlenmelerde başlıca nedenler olarak belirlendi. Akut alevlenmeleri önlemek için hastaların eğitimi ve yakın takibi önem kazanmaktadır.

Anahtar Kelimeler: Kronik hepatit B, akut alevlenme, reaktivasyon, kronik karaciğerde akut yetmezlik 


\section{Introduction}

Hepatitis B virus (HBV) infection is a major public health problem as a reason of morbidity and mortality in the world. It is estimated that there are more than 350 million carriers of HBV in the world, and approximately one million people die due to HBVrelated liver disease (1). Turkey is among the middle-endemic countries for HBV infection. HBsAg prevalence is about $4-6 \%$ and varies by region (2). The natural course of chronic HBV infection consists of five stages: Immune tolerant-phase, immunoreactive $\mathrm{HBeAg-positive} \mathrm{phase} \mathrm{(immune} \mathrm{clearance),} \mathrm{inactive} \mathrm{HBV} \mathrm{carrier}$ phase, HBeAg-negative chronic hepatitis B phase (reactivation), and HBsAg-negative phase. These stages are not necessarily sequential and all steps may not occur in the same patient (3). In the course of chronic HBV infection, acute exacerbation may occur spontaneously or due to the presence of several predisposing factors and may progress to acute liver failure accompanied by jaundice and hepatic decompensation (acute-on-chronic liver failure). Acute exacerbations of chronic hepatitis $B$ is a condition characterized by elevated serum ALT and HBV DNA levels with an increase or re-appearance of the liver necroinflammatory activity (4). It is thought that increased host immune response against HBV-infected hepatocytes often leads to the clinical picture. Acute exacerbation develops in $\mathrm{HBeAg}$-positive patients during the immune clearance of hepatitis B infection or with spontaneous immune reactivation in $\mathrm{HBeAg}$-negative patients in this way. In addition, due to various factors, such as withdrawal of nucleoside/ nucleotide analog, resistance, toxicity or interferon associated immune stimulation, pregnancy, hepatitis $A$ virus (HAV), hepatitis $E$ virus (HEV), hepatitis delta virus (HDV), and HIV superinfections and development of genetic variation in HBV (precore/core promoter mutant, HBV DNA polymerase mutant) can be encountered in this situation $(4,5,6,7,8,9,10)$. Sometimes, in inactive hepatitis $B$ even in HBsAg-negative and anti-HBc lgG-positive patients, as a result of the suppression of the immune system due to cytotoxic chemotherapy, immunosuppressive therapy or treatment given after organ transplantation causes the increased viral replication and this leads to exacerbation. Acute exacerbation of chronic hepatitis $B$ is an important condition leads to hepatic decompensation especially in patients who have high liver inflammation and fibrosis scores. Therefore, close follow-up of the patients and starting antiviral therapy without delay in severe cases is recommended. In our study, the reasons that lead to acute exacerbations in patients with chronic hepatitis B are evaluated and it is aimed to draw attention to them.

\section{Materials and Methods}

We retrospectively evaluated patients who were followed up with acute exacerbation of chronic hepatitis $B$ in the infectious diseases and clinical microbiology clinic at Ankara Training and Research Hospital between 2010 and 2014.

The patients were determined by using clinical database and data were obtained from patients' files. Acute exacerbation was diagnosed by detection of five-fold increase or more than twice of the previous values in ALT levels and increase of HBV DNA (>105 IU) in HBsAg-positive patients with a known history of chronic hepatitis B. Age, gender, duration of HBV infection, previous or current treatment for hepatitis B, drug and/or alcohol use and information about the gestation together with laboratory values ( $\mathrm{HBeAg}$ and anti-HBc IgM, ALT, AST, albumin, prothrombin time, and HBV DNA levels, delta antibodies) were recorded. The causes of acute exacerbation, such as additional infection, drug use due to another disease, additional diseases, use of herbal medicines, alcohol abuse, and use of immunosuppressive agents were revised. SPSS 16.0 software was used for statistical analysis.

\section{Results}

Fourteen patients (8 females; $57.1 \%$ and 6 males; $42.9 \%$ ) were diagnosed with acute exacerbation in our clinic in four years. The mean age of the patients was 41.5 years (range: 20-71). All the patients were previously diagnosed with HBV infection (minimum: 1 year, maximum: 28 years, average: 6.4 years). The mean ALT level was $912 \mathrm{U} / \mathrm{L}$, and HBV DNA level was $2 \times 10^{8} \mathrm{IU} / \mathrm{mL}$. HBeAg was positive in five patients. Anti-HBc IgM was positive in three of 12 patients. Clinical features and laboratory findings of the patients are shown in Table 1.

When the possible causes that lead to exacerbation were investigated; it was thought that acute exacerbations occurred because of pregnancy in four patients, antiviral therapy discontinuation in three patients, spontaneous activation in two and $\mathrm{HBeAg}$ seroconversion during interferon therapy, alcohol use, herbal medicine use (artichoke vinegar), methotrexate use, an infectious disease (acute gastroenteritis) in one patient each. Interferon therapy had been initiated in one of the patients before pregnancy. After receiving 12 doses pegylated-interferon treatment, she got pregnant. Therefore, treatment was stopped immediately. Unfortunately, two weeks after stopping the treatment, acute exacerbation was diagnosed. The reasons that lead to acute exacerbation are summarized in Table 2.

Jaundice was seen and prothrombin time prolonged gradually in one patient with compensated cirrhosis and exacerbation was due to spontaneous immune reactivation. Acute-on-chronic liver failure developed in the patient, and she was referred to a transplantation center. In another patient who had cirrhosis and exacerbation due to alcohol use, clinical course and laboratory values were more severe than in other patients. All these patients were consulted with gastroenterology. Clinical course of the other 12 patients

Table 1. Clinical and laboratory characteristics of patients $(n=14)$

\begin{tabular}{|l|l|}
\hline The average age & $42(20-71)$ years \\
\hline Female/male & $8 / 6$ \\
\hline Hepatitis B infection duration & 6.4 years (1-28 years) \\
\hline ALT mean & $912.2 \mathrm{U} / \mathrm{L}(153-2800)$ \\
\hline HBV DNA mean & $2 \times 10^{8} \mathrm{IU} / \mathrm{ml}\left(2.7 \times 10^{4}-1 \times 10^{9}\right)$ \\
\hline Prothrombin time & $14.7 \mathrm{~second}(12.4-22)$ \\
\hline Serum albumine & $3.9 \mathrm{~g} / \mathrm{dL}(2.5-4.7)$ \\
\hline HBeAg positivity & $5 / 14$ \\
\hline Anti HBc IgM positivity & $3 / 12$ \\
\hline
\end{tabular}

ALT: Alanine aminotransferase, HBV: Hepatit B virus 


\begin{tabular}{|l|l|}
\hline $\begin{array}{l}\text { Table 2. Causes of acute exacerbations in chronic hepatitis B patients } \\
(\mathrm{n}=14)\end{array}$ \\
\hline Possible causes & 4 \\
\hline Pregnancy & 3 \\
\hline Discontinuation of antiviral treatments & 2 \\
\hline Spontaneous & 1 \\
\hline HBeAg seroconversion during interferon therapy & 1 \\
\hline Alcohol use & 1 \\
\hline Herbal medicine use & 1 \\
\hline Methotrexate administration & 1 \\
\hline Acute infection &
\end{tabular}

without cirrhosis were better, their liver enzymes and HBV DNA levels decreased progressively. We continued to treat patients who had adherence problems with the drugs previously used. The patient whose exacerbation was a result of $\mathrm{HBeAg}$ seroconversion during interferon therapy was hospitalized and monitored. Antiviral therapy (lamivudine or tenofovir disoprixil fumarate) was given to all other patients.

\section{Discussion}

Chronic HBV infection is a dynamic process; there is an interaction between the virus, immune response and hepatocytes. It has been reported that spontaneous exacerbations may occur at an annual rate of $10-30 \%$ cumulatively during the natural course of chronic hepatitis B (6). In this study, since the majority of the patients with acute exacerbation were admitted to our clinic for the first time, we could not give an overall rate. This was the most important reason for the limitation in our study.

There are different definitions for exacerbations of chronic hepatitis B (flare, exacerbation, acute-on-chronic liver failure). The common features in these definitions are increase in the serum ALT level, HBV DNA level and liver necroinflammator activity. While further increase in normal serum ALT level was considered a criterion previously, increase at least five-fold the upper value of normal ALT levels or an increase in ALT values more than twofold, are acceptable criteria recently (11). This study is based on these criteria to determine the patients with acute exacerbation. Sometimes it is difficult to distinguish acute exacerbations of chronic hepatitis B from acute hepatitis B, especially in newly diagnosed patients. Thus, a careful patient history should be taken. Since $\mathrm{HBc} \operatorname{lgM}$ is one of the most important markers of acute infection, $\mathrm{HBc}$ lgM test can also be positive in acute exacerbations. Acute exacerbation of chronic hepatitis is together with high serum HBV DNA level, low titer of anti-HBc lgM and high titer of HBsAg. Low HBeAg titer, other tests such as increased alpha-fetoprotein titer may be useful in diagnosis. Biopsy may not help at early stage, it is recommended to perform after acute phase (12). One of our patients was admitted with very high serum ALT (2800 IU) and bilirubin (total bilirubin $17 \mathrm{mg} / \mathrm{dL}$ ) levels. In this study, three patients $(25 \%)$ were found to be positive for anti-HBc IgM. All patients had a history of HBsAg positivity previously known, therefore we did not get any problem in the diagnosis of acute exacerbation.
HBV DNA levels in the patients were also high (average $2 \times 10^{8} \mathrm{IU} /$ $\mathrm{mL}$ ). Many conditions can cause acute exacerbation of chronic hepatitis B. Today, cytotoxic or immunosuppressive therapy in patients with chronic hepatitis $B$ is a fairly well known condition that may lead to reactivation. Suppression of the immune response or stimulation of viral replication plays a role in this mechanism (5). Methotrexate and corticosteroid were started in one of our patients for rheumatoid arthritis. She was admitted to our clinic for the first time due to reactivation at the third month of immune suppressive treatment.Pregnancy was determined as the cause of exacerbation in four patients. In one of these patients, interferon treatment had been stopped due to pregnancy and two week later, the exacerbation occurred. It has been shown in some previous studies that exacerbation might appear during pregnancy in patients with chronic hepatitis $B$; even severe liver failure may develop $(13,14,15,16)$. Exacerbations are usually seen in the last trimester, more often in the post-partum period. However, in our patients, it has been identified in the first trimester. Activation in pregnancy might be related to the initial ALT and HBV DNA levels (16). Because there were no previous test results for hepatitis $B$ in pregnant patients, we could not comment on this issue. It is recommended that all pregnant women be screened for HBV infection and chronic hepatitis infections should be closely observed for mother and baby's health $(17,18)$.

It was thought that alcohol use caused exacerbation in one patient and an herbal medicine use caused it in another patient. Additionally, three patients had stopped antiviral treatment by themselves without the physician's recommendation. Adherence to treatment is one of the most important issues in chronic hepatitis B. Nonadherence leads to both antiviral resistance and exacerbation $(19,20)$.

An acute exacerbation was detected in a patient after a severe gastroenteritis. It is known that infections may also lead to exacerbation. However, there are no data in the literature about acute gastroenteritis as a cause of exacerbation in chronic hepatitis $B$ infections. Oral antiviral absorption might be impaired due to diarrhea.

Acute exacerbation was developed in one patient during interferon therapy and $\mathrm{HBeAg}$ seroconversion detected. Acute exacerbations are reported during the use of interferon and it may be seen in approximately $30 \%$ of HBeAg-positive patients treated with pegylated interferon. Usually HBV DNA levels decrease and the high rate of HBeAg loss are seen in these patients $(20,21)$.

Any specific cause could not be found in two patients and it is thought that the activation occurred spontaneously. Exacerbations can be seen more commonly in HBeAg-positive patients in the natural course of chronic HBV infection. The clinic presentation may be asymptomatic or symptomatic, mimicking acute hepatitis, even it can go up to hepatic decompensation and failure $(6,10,22)$. In one of our patients, decompensated cirrhosis developed and she had to be sent to a transplant center with acute failure on chronic basis.

Antiviral therapy is recommended in patients with acute exacerbation to prevent a higher degree of liver damage $(23,24,25)$. In this study, antiviral therapy (lamivudine or tenofovir disoproxil fumarate) was given to all patients previously untreated and, except in one patient mentioned above, it seemed successful. 
As a result, it was observed that treatment nonadherence and pregnancy are the most frequent causes of exacerbation. Although, causes may change according to social and cultural factors, patients's education and close monitoring of hepatitis $B$ patients are important to prevent or minimize acute exacerbation. Patients should be warned about the use of alcohol, toxic drugs or herbal substances for the liver.

Ethics Committee Approval: Because of the retrospective structure of the study, and used only our clinical data, there is no ethic committee approval, Informed Consent: Informed consent was received from all the patients, Concept: Necla Tülek, Design: Necla Tülek, Data Collection or Processing: Çiğdem Moroğlu, Ebru Aktepe, Analysis or Interpretation: Fatma Şebnem Erdinç, Günay Tuncer Ertem, Murat Kekilli, Literature Search: Necla Tülek, Meliha Çağla Sönmezer, Metin Özsoy, Writing: Çiğdem Moroğlu, Necla Tülek, Peer-review: External and Internal peer-reviewed, Conflict of Interest: There is no conflict of interest, Financial Disclosure: The authors declared that this study has received no financial support.

\section{References}

1. Global policyreport on thepreventionandcontrol of viralhepatitis in WHO MemberStates. World Health Organization, Ceneva 2013.

2. Toy M, Önder FO, Wörmann T, Bozdayi AM, Schalm SW, Borsboom GJ, van Rosmalen J, Richardus JH, Yurdaydin C. Age- and region-specific hepatitis B prevalence in Turkey estimated using generalized linear mixed models: a systematic review. BMC Infect Dis. 2011; 11: 337.

3. Kuo A, Gish R. Chronic hepatitis B infection. Clin Liver Dis. 2012;16: 347-369.

4. Hoofnagle JH. Reactivation of Hepatitis B. Hepatology. 2009; 49: 156-165.

5. Lau GK.Hepatitis B reactivation after chemotherapy: two decades of clinical research. Hepatol Int. 2008; 2: 152-162.

6. Perrillo RP. Acute flares in chronic hepatitis B: the natural and unnatural history of an immunologically mediated liver disease. Gastroenterology. 2001; 120: 1009-1022.

7. Jeng WJ, Sheen IS, Liaw YF. Hepatitis B virus DNA level predicts hepatic decompensation in patients with acute exacerbation of chronic hepatitis B. Clin Gastroenterol Hepatol. 2010; 8: 541545.

8. Tan AT, Koh S, Goh W, Zhe HY, Gehring AJ, Lim SG, Bertoletti A. A longitudinal analysis of innate and adaptive immune profile during hepatic flares in chronic hepatitis B. J Hepatol. 2010; 52: 330-339.

9. Liaw YF, Chu CM. Hepatitis B virus infection. Lancet. 2009; 373: 582-592.

10. Lok AS, Lai CL. Acute exacerbations in Chinese patients with chronic hepatitis B virus (HBV) infection. Incidence, predisposing factors and etiology. J Hepatol. 1990; 10: 29-34.
11. Chang ML, Liaw YF. Hepatitis B flares in chronic hepatitis B: pathogenesis, natural course, and management. J Hepatol. 2014; 61: 1407-1417.

12. Puri P. Acute Exacerbation of chronic hepatitis B: the dilemma of differentiation from acute viral hepatitis B. J Clin Exp Hepatol. 2013; 3: 301-312.

13. Nguyen G, Garcia RT, Nguyen N,Trinh H, Keeffe EB, Nguyen $\mathrm{MH}$. Clinical course of hepatitis $\mathrm{B}$ virus infection during pregnancy. Aliment Pharmacol Ther. 2009; 29: 755-764.

14. Giles ML, Visvanathan K, Lewin SR, Sasadeusz J. Chronic hepatitis B infection and pregnancy. Obstet Gynecol Surv. 2012; 67: $37-44$

15. Singhal A, Kanagala R, Jalil S, Wright HI, Kohli V. Chronic HBV with pregnancy: reactivation flare causing fulminant hepatic failure. Ann Hepatol. 2011; 10: 233-236.

16. Li XM, Deng LZ, Shen HM, Yang YB, Li MX, Chen XW, Yin YZ, Zhou SS. Liver synthetic function in predicting the prognosis of pregnancy complicating fulminant hepatitis. Chin Med J (Engl). 2007; 120: 2311-2313.

17. Aktuğ-Demir N, Asan A, Ayaz C, Çelen MK, Köse Ş, Kuruüzüm Z, Örmen B, Saltoğlu N, Sayan M, Sırmatel F, Koruk Tekin S, Tülek N, Türker N, Ural O, Yazıcı S. Management of Chronic Hepatitis B in Pregnancy: A Consensus Report of the Study Group for Viral Hepatitis of the Turkish Society of Clinical Microbiology and Infectious Diseases. Klimik Journal 2013; 26(Suppl 1): 12-19.

18. Lieveld FI, vanVlerken LG, Siersema PD, van Erpecum KJ. Patient adherence to antiviral treatment for chronic hepatitis $B$ and C: a systematic review. Ann Hepatol. 2013; 12(3): 380-391.

19. Çelen MK.Effect of physician-patient in compatibility on drugresistance in patient with chronic hepatitis B. Turkiye Klinikleri J Inf Dis-Special Topics. 2013; 6: 909-913.

20. Nair S, Perrillo RP. Serum alanine aminotransferase flares during interferon treatment of chronic hepatitis $B$ : is sustained clearance of HBV DNA dependent on levels of pretreatment viremia? Hepatology. 2001; 34: 1021-1026.

21. Flink HJ, Sprengers $D$, Hansen $B E$, van Zonneveld $M$, de Man RA, Schalm SW, Janssen HL; HBV 99-01 Study Group. Flares in chronic hepatitis $B$ patients induced by the host or the virus? Relation to treatment response during Peg-interferon \{alpha\}-2b therapy. Gut 2005; 54: 1604-1609.

22. Seto WK, Lai CL, Yuen MFAcute-on-chronic liver failure in chronic hepatitis B. J Gastroenterol Hepatol. 2012; 27: 662-669.

23. Yu W, Zhao C, Shen C, Wang Y, Lu H, Fan J. The efficacy and safety of Nucleos(t)ide analogues in patients with spontaneous acute exacerbation of chronic hepatitis $B$ : a systematic review and meta-analysis. Plos One. 2013; 8: 65952.

24. Jindal A,Kumar M, Sarin SK. Management of acute hepatitis B and reactivation of hepatitis B. Liver Int. 2013; 33 (Suppl 1): 164-175.

25. European Association For The Study Of The Liver. EASL clinical practice guidelines: Management of chronic hepatitis B virus infection. J Hepatol. 2012; 57: 167-185. 